PRACE GEOGRAFICZNE

zeszyt 164, 2021, 27-45

doi: 10.4467/20833113PG.21.003.13428

Instytut Geografii i Gospodarki Przestrzennej UJ

Komisja Geograficzna, Polska Akademia Umiejętności

Wydawnictwo Uniwersytetu Jagiellońskiego

\title{
KATOLICKIE KLASZTORY KONTEMPLACYJNE I ŻYCIE ZAKONNE W POLSCE W KONTEKŚCIE TURYSTYKI
}

\author{
Dagmara Chylinska
}

\section{Catholic contemplative monasteries and the consecrated life in Poland in the context of tourism}

Abstract: Visiting monasteries and staying there have become an attractive tourist experience shared by numerous tourists and perceived by them as truly "touching and authentic". Not only is a monastery in itself a subject of tourists' interest with all of its physical attributes, but also the idea and the specific way of life behind it. In the paper, a special attention was paid to the participation of Polish contemplative monasteries in the so-called "monastic tourism", in order to establish to what extent this phenomenon is close to religious tourism as well as to different forms of cultural tourism meant in the broad sense. Answers to these questions should lie in the results of a survey conducted among the Polish contemplative monasteries preceded by an analysis of motivations and conditions transforming 'a monastery' into a tourist destination (external individual attributes such as history and architecture were rejected).

Keywords: contemplative monasteries, monasticism, monastic tourism, Poland

Zarys treści: Odwiedzanie klasztorów i pobyt w nich staje się atrakcyjnym doświadczeniem turystycznym będącym udziałem coraz większej liczby turystów i postrzeganym przez nich jako „głębokie i autentyczne”. Przedmiotem zainteresowania odwiedzających jest nie tylko klasztor sam w sobie, ze wszystkimi atrybutami jego fizyczności, lecz także stojąca za nim idea i styl życia mieszkających w nim ludzi. W artykule zwrócono uwagę na udział polskich klasztorów kontemplacyjnych w tzw. turystyce monastycznej oraz postawiono sobie za cel 
udzielenie odpowiedzi na pytanie: na ile zjawisko to pokrywa się w Polsce z turystyką religijną, a na ile wpisuje się w szeroko pojmowaną turystykę kulturową i jej wybrane rodzaje. Odpowiedzi na te pytania mają dostarczyć wyniki badań ankietowych przeprowadzonych w klasztorach klauzurowych w Polsce, poprzedzonych analizą uwarunkowań i motywacji, które sprawiają, że klasztor, po odrzuceniu innych, ,zewnętrznych” jego atrybutów takich jak historia czy architektura, staje się destynacją turystyczną.

Stowa kluczowe: klasztory klauzurowe/kontemplacyjne, monastycyzm, turystyka monastyczna, Polska

Klasztory, miejsca odosobnienia, podporządkowane sacrum, mistyczne, od początku swego istnienia były postrzegane jako przestrzeń szczególna, a poprzez swój ekskluzywny charakter: tajemnicza, by nie powiedzieć „nieziemska”. Tradycje życia monastycznego sięgają wielu wieków wstecz i towarzyszą wielu religiom, w tym chrześcijaństwu. Choć ideały i wzorce życia zakonnego ulegały licznym przemianom, a współcześnie coraz częściej mówi się o kryzysie powołań (Jonveaux 2014), w klasztorach nadal żyją, pracują, modlą się i kontemplują dziesiątki tysięcy mnichów oraz mniszek. Tylko w Kościele katolickim w 2019 r. ponad 51 tys. mężczyzn i prawie 649 tys. kobiet uczestniczyło w różnych formach życia konsekrowanego (Catholic Church Statistics 2019). Mimo iż życie klasztorne braci i sióstr koncentrowało się na praktykach religijnych podejmowanych za murami klasztorów, one same oddziaływały silnie na świat zewnętrzny. W przeszłości klasztory zagospodarowywały przestrzeń wokół nich, odpowiadały za rozwój nowoczesnych i wydajnych praktyk rolniczych, prowadziły działalność opiekuńczą, charytatywną i edukacyjną, często w zgodzie z mottem św. Benedykta z Nursji: Ora et labora. Wspaniałe budowle klasztorne, wznoszone „na chwałę Boga”, a człowiekowi na pożytek, miejsce specyficznych często praktyk religijnych, w dobie powszechnego i masowego rozwoju turystyki stały się przedmiotem zainteresowania nie tylko turystów religijnych (Jackowski 2003), ale także innych kategorii turystów: przede wszystkim uczestników różnych form turystyki kulturowej, począwszy od turystyki dziedzictwa po turystykę kulinarną. Pogłębiający się dystans między warunkami życia w zakonie i wartościami, którymi się ono kieruje, a egzystencją we współczesnym, dynamicznie zmieniającym się świecie zewnętrznym, sprawia, iż ten pierwszy, prosty i zhierarchizowany model życia zakonnego może wydawać się bezpieczny i swojski także z perspektywy osób świeckich, w tym również tych niewierzących.

Celem artykułu jest wstępne oszacowanie, w jakim stopniu polskie klasztory kontemplacyjne uczestniczą w tzw. turystyce monastycznej, oferując świeckim możliwość czasowego odosobnienia, psychologicznej ucieczki, duchowego lub religijnego wsparcia czy po prostu oderwania się od własnej codzienności poprzez uczestnictwo w życiu codziennym innych, w tym wypadku mnichów i mniszek. Do szczegółowych badań wybrano klasztory kontemplacyjne, które w subiek- 
tywnej ocenie autora tej pracy najlepiej uosabiają popularne wyobrażenia o życiu zakonnym, czym mogą przyciągać specyficzną grupę odwiedzających. Analizie poddano wyniki badania ankietowego, które skierowano do 89 klasztorów kontemplacyjnych, uzyskując zwrot kwestionariuszy na poziomie 28,1\% (25 klasztorów). Przygotowano dwie wersje ankiety (załącznik 1 i 2), dla klasztorów przyjmujących świeckich i tych, które tego nie robią, wyraźnie zaznaczając, iż cenne są odpowiedzi obu tych grup klasztorów. Badanie przeprowadzono w lutym i marcu 2020 r., rozsyłając ankietę drogą mailową (korzystając m.in. z bazy teleadresowej dostępnej na stronie Konferencji Przełożonych Żeńskich Klasztorów Kontemplacyjnych) lub w przypadku negatywnej weryfikacji adresu mailowego tradycyjną pocztą wraz z zaadresowaną kopertą zwrotną zachęcającą do odesłania ankiety. Klasztory, które otrzymały ankietę mailem z linkiem do formularza ankiety wykonanym w serwisie Survio, miały dołączone również ankiety w wersjach edytowalnych plików elektronicznych z możliwością wydruku i odesłania na wskazany adres. Kwestionariusze ankiety, kierowane do dwóch grup klasztorów, prowadzących lub nie interesującą badaczy działalność, liczyły odpowiednio 11 i 5 rozbudowanych, w przeważającej części, zamkniętych pytań.

Właściwą analizę rezultatów badania ankietowego poprzedza opis potencjalnych uwarunkowań, które mogą decydować o potrzebach świeckich realizowanych poprzez odwiedziny lub pobyt w klasztorach katolickich (kontemplacyjnych) w celach wykraczających poza zwykłe zwiedzanie/poznanie lub motywacje religijne.

\section{Turystyka monastyczna}

Zjawisko odwiedzania klasztorów wynikające nie tylko z zainteresowań kulturowych i poznawczych, ale w celu doświadczania życia monastycznego i oferowanej przez nie psychologicznej ucieczki określa się mianem turystyki monastycznej (ang. monastic tourism). Praktykowanie tej formy turystyki wyraża się zarówno w postaci: 1) okazjonalnego uczestnictwa w praktyce religijnej klasztorów (udział we mszach, rekolekcjach, obchodach świąt religijnych itp.), zwykle w postaci krótkiego pobytu, lub 2) dłuższego pobytu w domach/pokojach gościnnych działających w/przy klasztorach w celu odosobnienia lub uczestnictwa w zajęciach organizowanych przez wspólnotę religijną (van Tongeren 2016). Nie jest to zatem w pełni i jedynie turystyka religijna, podporządkowana wybranemu wyznaniu, bo pobyt za murami klasztoru może być doświadczeniem uniwersalnym, duchowym (ale niewypływającym z klasycznie rozumianej religijności), egzystencjalnym (duchowym), poznawczym lub wynikającym z ciekawości czy potrzeby odmiany. Sama turystyka religijna, jak zauważa Durydiwka (2020), coraz częściej staje się zjawiskiem wielowymiarowym, różnorodnie motywowanym, coraz mocniej ciążącym ku bardziej neutralnej światopoglądowo turystyce 
kulturowej. Wśród turystów odwiedzających klasztory z motywacji religijnych autorka wyróżniła dwie wyraźne grupy: uczestników indywidualnych rekolekcji oraz uczestników grupowych rekolekcji. Na podstawie motywacji pozareligijnych zdefiniowała natomiast: 1) kategorię gości przyjeżdżających w celu poznania walorów przyrodniczych i kulturowych okolicy, w której znajduje się klasztor, korzystających z niego samego jak z każdej innej komercyjnej bazy noclegowej oraz 2) kategorię osób kierujących się chęcią sprawdzenia się w nowych dla nich warunkach, dla których pobyt w klasztorze jest niecodzienną, nieco egzotyczną przygodą. $Z$ motywacji mieszanych klasztory odwiedzają uczestnicy warsztatów i turnusów terapeutycznych, to jest osoby zmagające się z chorobami cywilizacyjnymi lub chcące odpocząć w bardziej psychologicznym niż fizycznym sensie. Główne tezy Durydiwki (2020) pozostają w zgodzie z obserwacjami Gilli i Palmisano (2016). Autorki, wnioskując w oparciu o doświadczenia katolickich klasztorów, zauważają, że turystyka ta zyskuje na znaczeniu nie tylko wśród turystów motywowanych religijnie (choć to nadal spora, szukająca odnowy i wzmocnienia wiary grupa), ale trafia do szerszej i bardziej zróżnicowanej grupy odbiorców (van Tongeren 2016). Obiekty sakralne, także klasztory, są coraz częściej traktowane przez odwiedzających je turystów, jak również ich gestorów, jak ,zwykły”, przeznaczony do konsumpcji produkt turystyczny (Durydiwka 2020; Ryan, Haslam-McKenzie 2003).

Typowy dla zakonników styl życia (lub jego idealistyczne wyobrażenie) jest tym, co przyciąga odwiedzających do klasztoru. Jak pisze Abbruzzese (2014), najbardziej charakterystycznym elementem życia zakonnego jest specyficzna organizacja dnia codziennego, którą cechuje współistnienie różnych rodzajów ascezy (zachowanie ciszy, modlitwa, medytacja) oraz najbardziej podstawowe i niezbędne formy pracy. W założeniu takie proste życie w tradycyjnie pojmowanym chrześcijaństwie ma prowadzić do zjednoczenia i poczucia bliskości z Chrystusem. Zarówno czynności religijne, jak i te całkiem prozaiczne podyktowane potrzebami ciała, jak sen, jedzenie czy odpoczynek, podporządkowane są ściśle reżimowi czasu. Tak zdefiniowany dowód dobrowolnego podporządkowania regule zakonnej, rezygnacji z osobistej wolności (we współczesnych społeczeństwach zachodnich przedkładających indywidualizm ponad kolektywizm), jawi się jako ostateczny wyraz oddania/ ofiarowania absolutowi. Życie lub pobyt w klasztorze uosabia również alternatywny wobec nowoczesności styl życia, umożliwiający osiągnięcie pełnego błogostanu fizycznego i psychicznego poprzez ciszę, spokój, równowagę, uważność, brak pośpiechu czy obcowanie z przyrodą. Ponadto wszystkie te uwarunkowania, które oferuje pobyt w klasztorze, zdaniem Gilli i Palmisano (2016), definiują prawdziwą „sztukę życia” tak bardzo atrakcyjną dla uczestników turystyki monastycznej. Uzasadnieniem faktu, iż idee życia monastycznego mogą pociągać nie tylko osoby motywowane religijnie, jest pogląd reprezentowany m.in. przez Webera (2014), iż nowożytny monastycyzm ma charakter racjonalny. W odróżnieniu od swoich 
początków, gdy ten model konsekrowanego życia zakładał mistrzostwo w umartwianiu się, życie w zakonie stało się „,systematyczną, przemyślaną metodą racjonalnego życia w celu przezwyciężenia status naturae, uwolnienia człowieka od władzy irracjonalnych popędów i podporządkowania supremacji wolnej woli, poddania własnych działań samokontroli i rozważeniu ich etycznego znaczenia” (Weber 2014, s. 85). Ascetyzm towarzyszący życiu monastycznemu od zarania jego początków nadal stanowi ważny jego składnik, przechodząc jednak od cielesnej do bardziej duchowej, intelektualnej dyscypliny (Jonveaux 2011).

Godnym odnotowania jest też fakt, iż życie w klasztorze może być interesujące dla szukających dla siebie (prywatnie lub w kontekście pracy) wartościowych modeli organizacji i zarządzania czasem. Przykładowo Jewdokimow (2017, s. 215), powołując się na pracę Kleymann i Malloch (2010), zwraca uwagę, iż niektóre elementy reguły św. Benedykta mogą przyczynić się do tworzenia i działania „,bardziej «ludzkich» organizacji”.

Szukając czynników sprzyjających rozwojowi turystyki monastycznej, warto podkreślić jej ogólne uwarunkowania psychologiczne, jak również te związane ze współczesną religijnością. Nowoczesność stawia przed człowiekiem wiele wyzwań i jest źródłem zarówno psychologicznego, jak i środowiskowego (hałas, smog, zanieczyszczenie światłem) stresu. Niepewność ekonomiczna, tempo życia, dynamika i jednocześnie powierzchowność relacji indywidualnych i społecznych oraz mnogość wyborów, przed którymi „codziennie” stajemy (od wyboru płatków śniadaniowych, koloru skarpetek, najbardziej efektywnego kredytu po decyzję o założeniu rodziny czy zgodę na oddanie organów po śmierci), może wywoływać nostalgię za czasami „kiedy życie było prostsze”. Doświadczanie anomii (Wrzesień 2017) sprzyja poszukiwaniom przestrzeni (w sensie dosłownym lub symbolicznym), które mogłyby pełnić funkcję takiego czasowego refugium - odskoczni od trudów i wyzwań dnia codziennego. Klasztor jawić się może jako takie właśnie schronienie. Wspólnotowy charakter życia monastycznego oraz jasno skodyfikowane jego zasady postrzegane są jako przeciwwaga dla chaosu świata zewnętrznego. Na terapeutyczne funkcje pobytu zachodnich turystów także w klasztorach, tym razem jednak buddyjskich, zwracają uwagę liczni autorzy, wśród nich Choe i McNally (2013 cytowani w Gilli, Ferrari 2017). W tym kontekście turystyka monastyczna może być traktowana jako jeden z rodzajów turystyki ucieczkowej (escape tourism).

Wśród wielu reguł zakonnych, jak chociażby tej stworzonej przez św. Benedykta z Nursji w VI w. n.e., praca fizyczna traktowana jest jako element odpowiedzialny za moralną dyscyplinę, bezczynność zaś to wróg duszy (Abbruzzese 2014, s. 10). Zatem uczestnictwo w różnych praktycznych zajęciach w klasztorze, zarówno mnichów, jak i gości, nabiera charakteru duchowego bądź terapeutycznego. Dzieje się tak również z uwagi na fakt, iż obecnie praca, której współczesny człowiek poświęca wiele sił, energii i czasu, nie przynosi namacalnych i natychmiastowych efektów, 
co nie pozwala dostrzec w takiej pracy głębszego sensu i czarpać z niej radość. Prosta, związana z wysiłkiem fizycznym praca, choć często ciężka, pozwala odczuwać satysfakcję „tu i teraz”.

Wśród powodów odwiedzania klasztorów dla czasowego w nich odosobnienia i doświadczania życia mnichów i mniszek wymienia się również wzrost znaczenia nowych, bardziej selektywnych form życia religijnego i odmienionego ruchu monastycznego (Palmisano, Jewdokimow 2019), w którym świeccy, obok mnichów i mniszek, mogą spędzać czas na modlitwie lub poświęcać go w całości na studiowanie lektur w bibliotece, pracę w ogrodzie czy w klasztornej kuchni (Cox Hall 2018; Gilli, Palmisano 2016). Te dwie ostatnie aktywności, w których mogą uczestniczyć odwiedzający klasztor, stanowią również magnes przyciągający do nich turystów poszukujących autentyczności w naturalnym (zioło)lecznictwie, tradycyjnej kuchni czy produktach przez wieki wytwarzanych przez zakonników według starych, oryginalnych receptur (np. Aulet i in. 2017). Sposób wytwarzania produktów, celebrowania cierpliwej, z pozoru tylko prostej pracy, mieści się w ideologii ruchu slow life, pozostając także w zgodzie (paradoksalnie) z ruchami ekologicznymi czy zielonymi. Otwieranie się klasztorów na świeckich, także bez wyraźnych motywacji religijnych, oferując im nocleg w domach gościnnych prowadzonych przez zakonników lub bezpośrednio w domach zakonnych, angażowanie się w sprawy świeckich i wychodzenie ze swoją działalnością ,za zewnątrz” nie jest jedynie swoistą działalnością „marketingową", podyktowaną jedynie chęcią kształtowania pozytywnego wizerunku zakonów i życia zakonnego, pozyskiwania młodych do obrania takiego stylu życia. To także w wielu przypadkach (choć nie jest to zawsze czynnik decydujący) wynik prozaicznych, nie zawsze pozytywnych uwarunkowań ekonomicznych, wynikających ze zmian sposobu finansowania zakonów czy innych obiektów sakralnych, służących ekskluzywnym praktykom religijnym (np. Ryan i Haslam-McKenzie 2003, s. 62). W przypadku klasztorów klauzurowych jednak, w których warunki życia są zazwyczaj bardzo skromne (Zimnica-Kuzioła 2015, s. 65), a model życia najbardziej zamknięty i skupiony na modlitwie, możliwości przyjmowania świeckich są z różnych przyczyn ograniczone, choć nie oznacza to, że wykluczone.

\section{Klasztory kontemplacyjne w Polsce}

Katolickie zgromadzenia zakonne w Polsce odgrywały szczególną rolę w historii zarówno ze względów ekonomicznych, patriotycznych, jak i społeczno-kulturowych. Nie rozwijając zanadto w tym miejscu szerokiego skądinąd zagadnienia, warto wymienić jedynie wkład cystersów/cysterek w zagospodarowanie ziem Śląska dzięki klasztorom w Lubiążu, Henrykowie czy Trzebnicy, rolę klasztoru oo. Paulinów na Jasnej Górze w podtrzymywaniu postaw patriotycznych i naro- 
dowych w najtrudniejszych momentach historii Polski, znaczenie benedyktynów w rozwoju i upowszechnieniu tradycji chorału gregoriańskiego, a pijarów i jezuitów w organizowaniu edukacji muzycznej. Na potrzeby klasztorów tworzyli dzieła religijne słynni artyści. Najlepszym tego przykładem był Michał Willmann, „Śląski Rembrandt”, którego warsztat znajdował się przy lubiąskim klasztorze. Dzieła malarza można dziś oglądać w obiektach sakralnych, dla których powstały (np. w kościele św. Józefa w Krzeszowie) lub są one prezentowane w kolekcjach muzealnych lub podczas czasowych wystaw (jak obrazy z rozkradzionego kościoła pw. NMP w opactwie lubiąskim prezentowane na wystawie „Opus magnum” w 2020 r. we Wrocławiu). W turystyce historyczne klasztory należą do najcenniejszych obiektów dziedzictwa architektonicznego kraju i są chętnie odwiedzane zarówno przez turystów kulturowych (turystów dziedzictwa), kierowanych ogólnymi motywacjami poznawczymi, jak i tych stricte religijnych (np. Podgórski i in. 2016). Wśród nich wyróżnia się m.in. dawne założenie klasztorne w Lubiążu z najdłuższą barkową fasadą w Europie, również barokowe założenie klasztorne w Krzeszowie, pocysterski zespół klasztorny w Henrykowie, klasztor oo. Paulinów na Jasnej Górze, opactwo benedyktyńskie w Tý́cu czy pokamedulski klasztor w Wigrach. Tylko niektóre z wymienionych jednak stanowią współcześnie domy dla zgromadzeń zakonnych.

Choć za sprawą różnych przemian, zarówno cywilizacyjnych, jak i tych związanych z życiem duchowym czy sferą religijną jednostek lub grup ludzkich, znaczenie zakonów i reprezentujących je klasztorów w życiu i gospodarce kraju zmalała, ideały życia zakonnego wdraża w praktyce tysiące wspólnot zakonnych. Liczba sióstr zakonnych w Polsce wynosiła w 2017 r. 17,9 tys. skupionych we 2,2 tys. wspólnotach zakonnych. Najliczniejsze zgromadzenia żeńskie to służebniczki starowiejskie, elżbietanki oraz szarytki (Annuarium... 2019). Według Konferencji Żeńskich Zgromadzeń Zakonnych w Polsce w 2018 r. wśród ogółu sióstr zakonnych profeski wieczyste stanowiły 16,6 tys. osób, profeski czasowe, nowicjuszki i postulantki odpowiedni po 603, 2013 i 173 osoby (https://zakony-zenskie.pl/ statystyka/, dostęp: 24.04.2020). Liczba zakonników oraz członków stowarzyszeń życia apostolskiego w analogicznym przedziale czasowym wynosiła łącznie 11,6 tys. osób, wśród zakonników 9,1 tys. (79\%) stanowili prezbiterzy (posiadający święcenie kapłańskie). Najliczniejszymi męskimi zgromadzeniami są franciszkanie, salezjanie oraz pallotyni (Annuarium... 2019). Według danych Instytutu Statystyki Kościoła Katolickiego SAC im. Witolda Zdaniewicza, w Polsce w klasztorach klauzurowych żyje też 1,3 tys. sióstr klauzurowych w 83 domach zakonnych (Annuarium ... 2019) z 13 zgromadzeń zakonnych (https://klauzura.katolik.pl/xhtml/statystyka/2019/, dostęp: 26.04.2020). Spośród męskich zakonów kontemplacyjnych w Polsce pozostali jedynie kameduli, żyjący obecnie w dwóch klasztorach (Kraków-Bielany, Bieniszew). W ramach tzw. Konferencji Przełożonych Żeńskich Klasztorów 
Kontemplacyjnych funkcjonują 83 klasztory, a cztery dalsze klasztory żeńskie są poza strukturami KPŻKK (https://klauzura.katolik.pl/xhtml/klasztory/adresy/, dostęp: 25.04.2020).

Jewdokimow (2017) pojęcie monastycyzmu odnosi do organizacji zakonów monastycznych, mnisi i mniszki to podtyp zakonników i zakonnic. Jak pisał Eliade (1994, s. 269), w chwili swoich narodzin w III w. n.e. ${ }^{1}$ monastycyzm, charakteryzujący się odsunięciem od świata i silnym ascetyzmem praktyk religijnych i życia codziennego, był innowacją odpowiedzialną za szereg zmian religijnych, kulturowych i społecznych w historii Europy. Ogółem zgromadzenia zakonne dzielą się na zakony monastyczne, nastawione na kontemplację i programowo odcinające się od świata zewnętrznego oraz zakony apostolskie. Te ostatnie silniej nastawione są na działanie poza murami klasztoru, najczęściej o charakterze duszpasterskim, misyjnym, ale także edukacyjnym, oraz wyspecjalizowanym opiekuńczym i pomocowym. Klasztor rozumiany jest przez autora jako instytucja koncentrująca swoich członków na poszukiwaniu Boga poprzez ucieczkę od świata, a to może odbywać się na różne sposoby (Jewdokimow 2017). Życie w klasztorach monastycznych wypełnia modlitwa (także prowadzona w zastępstwie innych, w zgłaszanych przez wiernych intencjach), kontemplacja i praca.

Jak wspomniano wyżej, w Polsce współcześnie (2020 r.) znajduje się 89 klasztorów kontemplacyjnych, w tym 83 żeńskie (oraz cztery poza strukturami KPŻKK) oraz dwa męskie. Zlokalizowane są one niemal w całej Polsce (ryc. 1), zarówno w miastach zróżnicowanych pod względem wielkości, od dużych aglomeracji po małe miasta, jak i na terenach wiejskich, niekiedy peryferyjnych. Najwięcej klasztorów klauzurowych znajduje się w Krakowie (dziewięć), cztery w Warszawie, po dwa we Wrocławiu, Łodzi i Elblągu, a biorąc pod uwagę województwa znaczną ich koncentrację można zauważyć w województwach: małopolskim, mazowieckim, wielkopolskim i łódzkim. Część z klasztorów zlokalizowanych jest w obiektach o wysokich walorach zabytkowych (jak np. Krzeszów, Przemyśl, Jarosław, opactwa krakowskie) lub/i w atrakcyjnej turystycznie okolicy (pod względem kulturowym, przyrodniczym, krajobrazowym lub wypoczynkowym, np. Bieniszew, Kraków-Bielany), co może przyciągać do klasztorów większą liczbę gości, których motywacje nie wynikają z pobudek religijnych, jednakże część z nich to współczesne, często też skromne siedziby. Ten ostatni fakt mógłby sugerować, iż jeśli klasztory te są odwiedzane przez świeckich, to przyciąga ich do nich bardziej „wewnętrzna” specyfika klasztoru i ludzie w nim żyjący w określony sposób niż inne „typowe” walory turystyczne.

\footnotetext{
${ }^{1}$ Prawdopodobnie równolegle w Egipcie, Palestynie, Syrii i Mezopotamii (Eliade 1994, s. 269).
} 


\section{Rezultaty badań}

Spośród 87 żeńskich klasztorów kontemplacyjnych (w tym 83 stowarzyszonych w tzw. Konferencji Przełożonych Żeńskich Klasztorów Kontemplacyjnych) i dwóch męskich, łącznie 25 (28,1\% ogółu klasztorów klauzurowych w Polsce) odpowiedziało na pytania zawarte w ankiecie o prowadzoną lub nie działalność klasztoru świadczoną na rzecz świeckich, a polegającą na zapewnieniu turystom czasowego w nim odosobnienia. Jak wspomniano we wstępie, badanie miało charakter pełny, przeprowadzone zostało w lutym-marcu 2020 r. przy pomocy formularza ankiety rozdysponowanego pocztą elektroniczną (lub tradycyjną, jeśli klasztor nie posiadał skrzynki mailowej) do klasztorów kontemplacyjnych w Polsce. Taką działalność prowadzi w tej grupie 12 klasztorów, z czego niemal połowa działa w oparciu o regułę św. Klary (aczkolwiek nie wszystkie zakony kontemplacyjne na regule św. Klary zadeklarowały taką działalność). Reguły zakonów biorących udział w badaniu przedstawia ryc. 2 .

Wszystkie one oferują świeckim pobyt lub odosobnienie na określony czas, przy czym świeccy organizują sobie czas i sposób modlitwy samodzielnie (11 z 12 klasztorów), pięć klasztorów równolegle stwarza możliwość nie tylko pobytu, ale także uczestnictwa we wspólnych modlitwach zgromadzenia zakonnego lub innych praktykach religijnych, ponadto po dwa klasztory oferują świeckim pobyt/odosobnienie bez wymogu podejmowania jakichkolwiek praktyk religijnych lub z możliwością pełnego uczestnictwa w codziennym życiu klasztoru poza czynnościami religijnymi zarezerwowanymi tylko dla członków zgromadzenia. Spośród „innych”, specjalnych form uczestnictwa świeckich w życiu zakonu wymieniono nocną lub dzienną nieustanną Adorację Najświętszego Sakramentu (1 klasztor). Poza dwoma klasztorami, które zadeklarowały, że przyjmują świeckich w opisanych celach od połowy XVII w., połowa klasztorów rozpoczęła taką działalność przed 1995 r., a połowa po tym roku (klasztory wskazywały też, iż działalność ta została rozpoczęta równolegle z powstaniem zgromadzenia). Niemal połowa klasztorów (w grupie, w której prowadzą opisaną działalność) przyjmuje wszystkich świeckich, którzy wyrażą taką potrzebę, dla kolejnych pięciu klasztorów decydująca jest motywacja religijna, dwa klasztory deklarują kierowanie się motywami religijnymi w połączeniu z innymi kryteriami (np. określając pożądaną płeć). Siedem z dwunastu klasztorów kontemplacyjnych przyjmujących świeckich robi to incydentalnie, pozostałe regularnie w związku z kalendarzem liturgicznym (1), ale cztery bez wyraźnego związku z kalendarzem liturgicznym. Pod względem możliwości uczestnictwa świeckich w różnych aktywnościach codziennego i religijnego życia klasztoru, klasztory polskie cechuje skromny zwykle zestaw czynności silnie skoncentrowany wokół podstawowych praktyk religijnych (ryc. 3). Obejmuje on uczestnictwo we mszy, zbiorowej modlitwie czy kontemplację. $Z$ zajęć pozareligijnych 


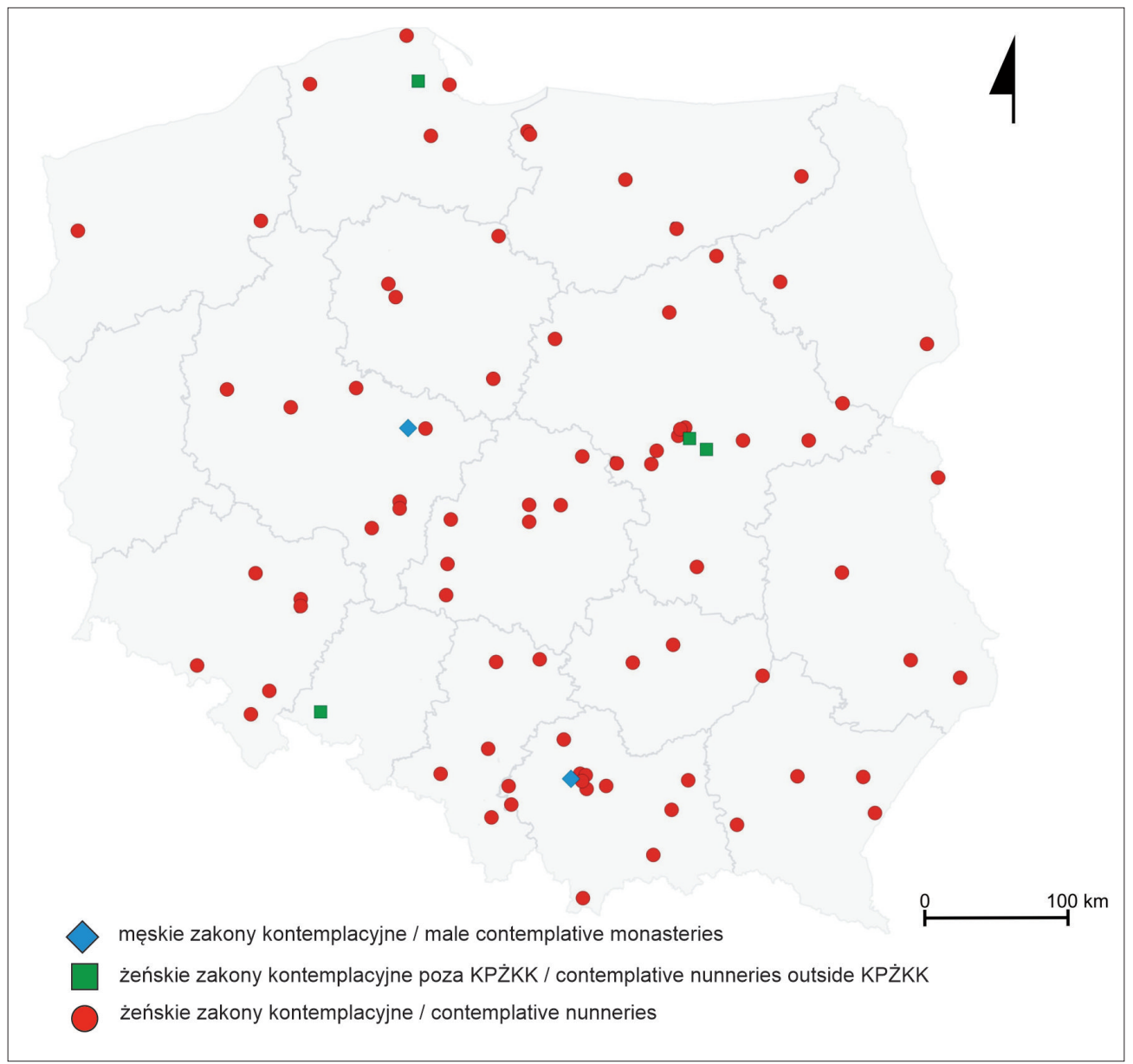

Ryc. 1. Klasztory klauzurowe w Polsce

Fig. 1. Contemplative monasteries in Poland

Źródto: opracowanie własne na podstawie danych Konferencji Przełożonych Żeńskich Klasztorów Kontemplacyjnych.

Source: own elaboration based on the data from „Konferencja Przełożonych Żeńskich Klasztorów Kontemplacyjnych". 


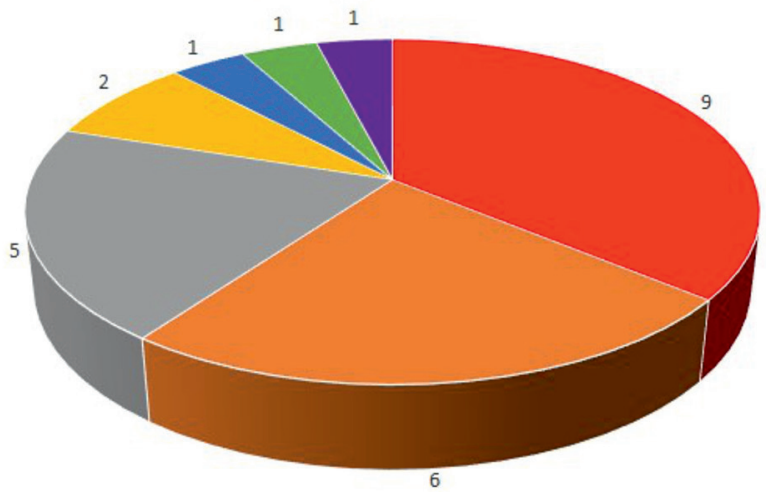

reguła św. Klary / St. Claire's rule

reguła karmelitańska / Carmelite rule

inne, w tym reguły własne / other within own rules

$\square$ reguła św. Benedykta i konstytucje własne / St. Benedict's rule and own rules

$\square$ reguła św. Benedykta oraz Konstytucja Eremitów Kamedułów Góry Koronnej / St. Benedict's rule and the rule of Camaldolese from Góra Koronna

$\square$ reguła augustiańska / Augustin rule

reguła św. Dominika / St. Dominic's rule

Ryc. 2. Klasztory ( $\mathrm{n}=25)$, które wzięły udział w badaniu, według reguły zakonnej

Fig 2. Investigated monasteries $(\mathrm{n}=25)$ according to their religious order (in the legend monasteries rules from the top as follow: St. Claire's rule, St. Benedict's rule and own rules, St. Benedict's rule and the rule of Camaldolese from Góra Koronna, Carmelite rule, other within own rules, Augustinian rule, St Dominic's rule) 


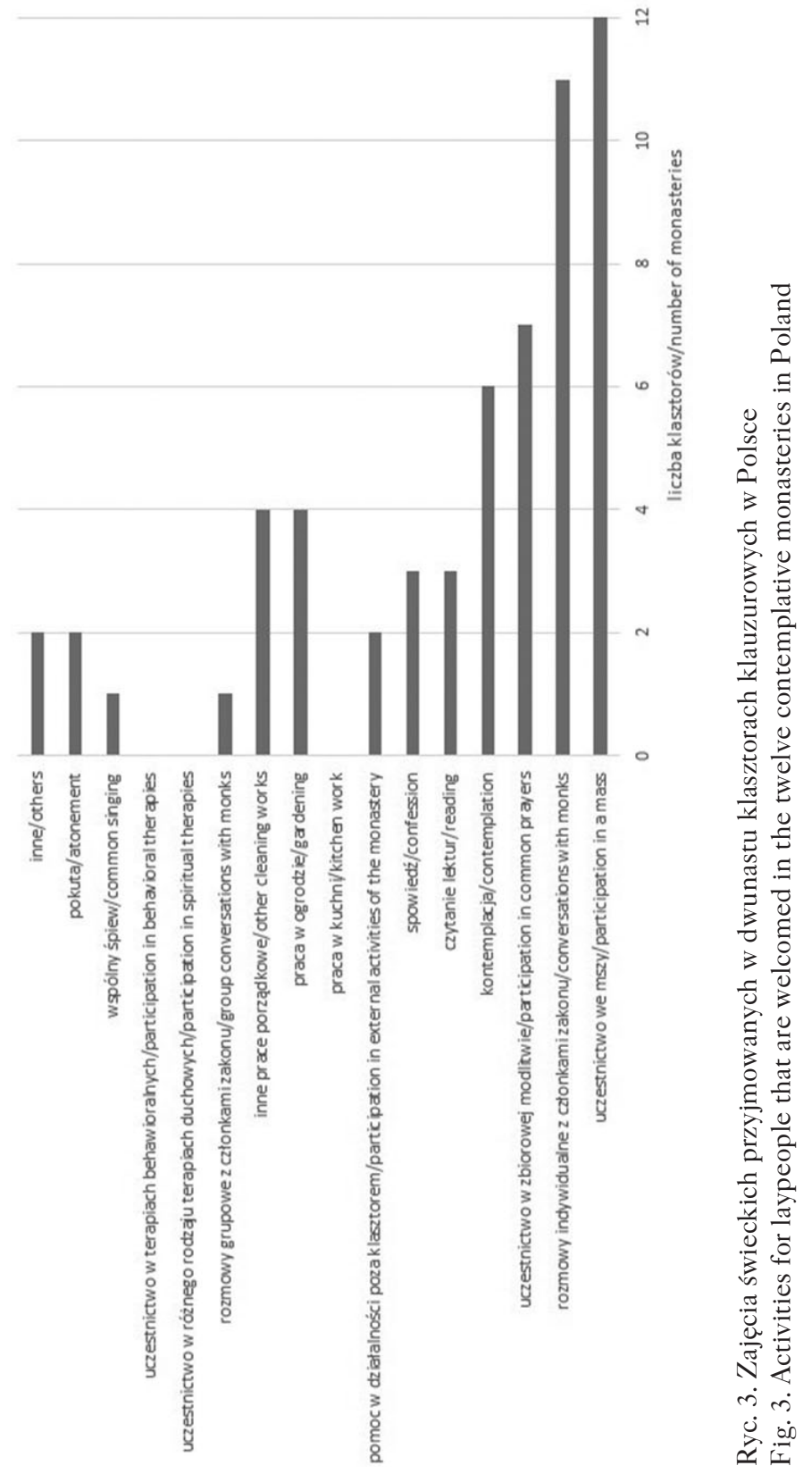


cztery klasztory oferują gościom możliwość pracy w ogrodzie. W dwóch z badanych klasztorów tradycja przyjmowania świeckich istnieje od połowy XVII w. (odpowiednio 1641 i 1663 r.). Oferują one gościom bogatszy wachlarz zajęć: nie tylko pracę w ogrodzie, ale też inne prace porządkowe czy lekturę. Opisywane tu zgromadzenia nie prowadzą działalności terapeutycznej w ścisłym tego słowa znaczeniu, ale oferują wsparcie duchowe/życiowe w postaci indywidualnych, rzadziej zbiorowych, rozmów z członkami zakonu.

Klasztory, na podstawie własnych doświadczeń, najczęściej opisują swoich gości jako osoby poszukujące odnowy religijnej lub religijnego rozwoju bądź osoby poszukujące sensu życia, szeroko rozumianej duchowości. Pojedyncze wskazania dotyczyły osób „zagubionych”, ciekawych zakonnego życia, szukających odmiany, wsparcia w obliczu cierpienia własnego lub bliskich albo utwierdzających się w powołaniu do zakonnego życia (ryc. 4). Klasztory przyjmujące gości, których pobyt trwa zwykle do siedmiu dni, deklarują ( 5 klasztorów), iż są to pojedyncze osoby albo kilkanaście lub kilkadziesiąt osób w ciągu roku (4 klasztory). Jednocześnie niemal wszystkie (11 klasztorów) opisują goszczoną społeczność jako „mieszaninę” osób odwiedzających klasztor jednorazowo oraz tych, którzy powracają od czasu do czasu lub wielokrotnie (także z zamiarem wstąpienia do wspólnoty religijnej). Dla jednego klasztoru odwiedzający go świeccy to w całości goście już „oswojeni”, powracający od czasu do czasu.

Odnosząc się do oszacowanych przez zgromadzenia zakonne rzędów wielkości odwiedzających je świeckich, należy zauważyć, iż chociaż nie są to imponujące liczby, wkład klasztorów kontemplacyjnych w rozwój turystyki monastycznej w Polsce jest zauważalny, tym bardziej iż większość z nich to zgromadzenia małe, w których żyje łącznie jedynie ponad 1200 mniszek i mnichów. Można zatem przypuszczać o ich ograniczonych możliwościach organizowania pobytu gości spoza zgromadzenia. Koresponduje to z wynikami ankiety wśród klasztorów kontemplacyjnych, które zadeklarowały, że nie przyjmują świeckich w celach zapewnienia im pobytu/odosobnienia. Dziewięć z trzynastu takich klasztorów nie robi tego z powodu niewystarczających warunków lokalowych, żywieniowych lub innych, tylko cztery ze względu na brak zgody na takie działania w regule zakonnej. Niemal połowa z tych klasztorów nie przewiduje w przyszłości zmiany swojej decyzji, pięć badanych jednostek jednak mogłoby podjąć się przyjmowania świeckich, gdyby nastąpiła zmiana warunków organizacyjnych, lokalowych lub żywieniowych klasztorów. Pojedyncze wskazania dotyczyły możliwości „otwarcia” się zgromadzenia na świeckich, gdyby zgłaszane były takie potrzeby przez nich samych. 
구

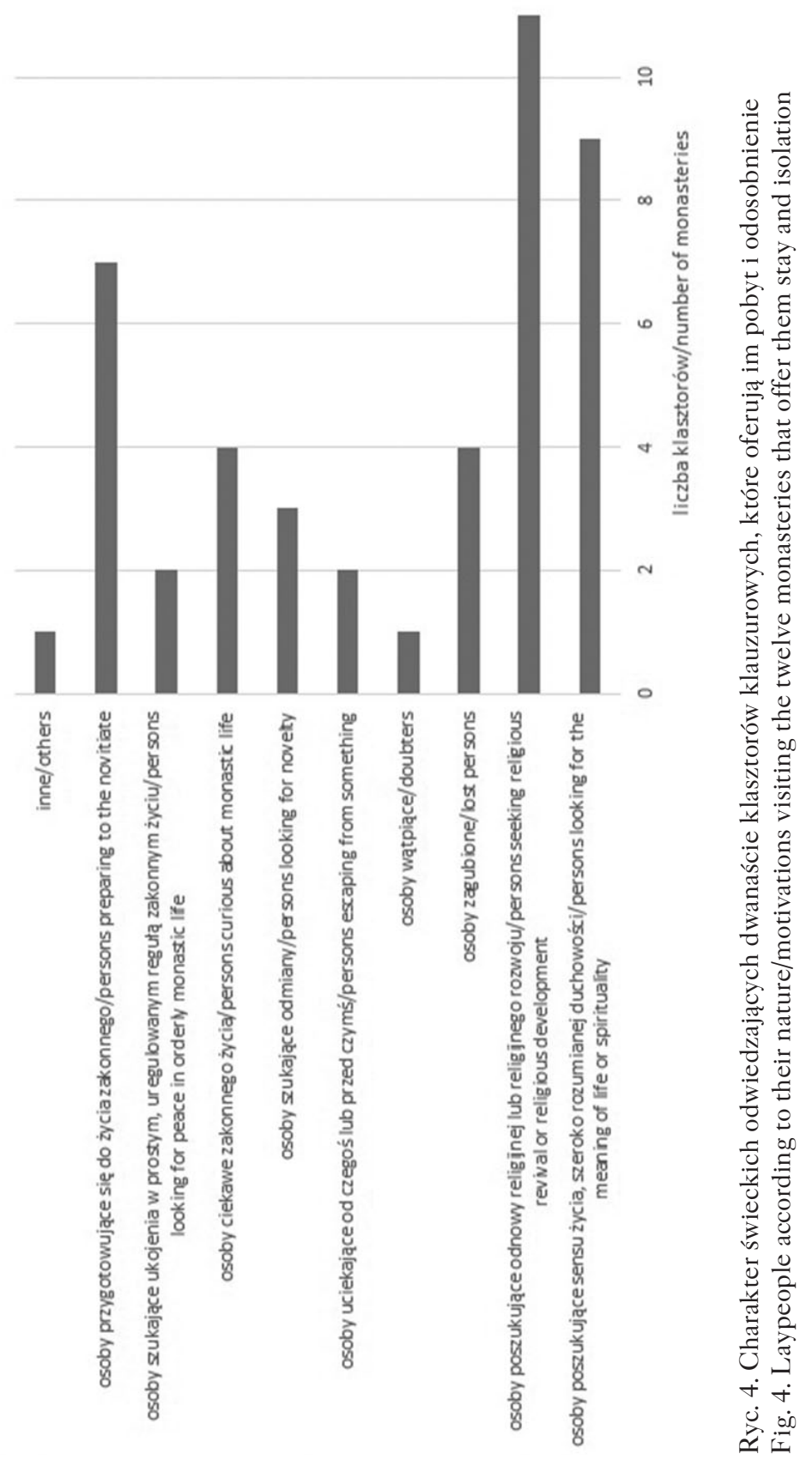




\section{Dyskusja i podsumowanie}

Jak już wspomniano, współczesne klasztory biorą udział w różnych formach turystyki, od szeroko pojętej turystyki kulturowej po turystykę religijną. Jak pisze Durydiwka (2020), część obiektów (zarówno tych „czynnych”, jak i poklasztornych) traktowana jest jak „zwykłe”, choć z pewnością pod względem specyfiki budowlanej czy historii nieszablonowe, obiekty noclegowe (s. 8) lub noclegowo-rekreacyjne z rozbudowaną ofertą wypoczynkową lub nawet SPA-Wellness. Nie wyklucza to oczywiście wizyt/ pobytów w klasztorach z motywacji wyłącznie religijnych. Fakt, iż klasztory klauzurowe dopuszczają pobyt w klasztorze osób świeckich niemotywowanych religijnie, świadczyć może pośrednio o „ucieczkowym” postrzeganiu klasztoru przez osoby spoza konsekrowanego życia zgodnie z jedną z jego podstawowych funkcji: azylu, bezpiecznego schronienia. Jednocześnie dla wielu współczesnych zakonów świadczenie usług turystycznych staje się sposobem na odnalezienie się w coraz bardziej zsekularyzowanym świecie, a poprzez korzystanie z produktu turystycznego powstałego na bazie klasztorów przez osoby nie tylko wierzące, oraz otwieranie przestrzeni klasztoru na niereligijnych turystów, krąg „odbiorców” działań klasztorów poszerza się, w czym Jonveaux (2014, cytowane za Jewdokimow 2017) widzi instrument ewangelizacji, „,nowy sposób integracji mnichów ze społeczeństwem”. W przypadku badanych klasztorów klauzurowych w Polsce wydaje się jednak, iż ta „popularyzacyjna" rola klasztoru w stosunku do świeckich jest traktowana marginalnie, co wydaje się o tyle naturalne, iż z natury są one ekskluzywne, skoncentrowane bardziej na rozwoju własnej duchowości niż innych. Choć wśród badanych w pracy klasztorów udział tych, które przyjmują świeckich i tych, które tego nie robią, rozłożył się niemal po połowie, ta druga grupa dość wyraźnie deklaruje brak potrzeby zmiany obecnego stanu rzeczy. Wyniki badań wskazują również, iż w Polsce turystyka monastyczna w klasztorach klauzurowych jest nadal w większym stopniu turystyką religijną (w części zapewne o charakterze ucieczkowym) niż inną formą turystyki kulturowej czy wypoczynkowej. Potwierdza to także jednorodność oferty zakonów klauzurowych, którą zauważa także w swoim badaniu Durydiwka² (2020, s. 10). Ta jednak pozorna „ubogość” aktywności oferowanych przez klasztor może jednak być postrzegana jako ich atut, gdyż w pewien sposób najbardziej oddaje istotę życia w zamkniętym dla świata i przed światem klasztorze. Obserwacje poczynione przez przełożone/ przełożonych klasztorów klauzurowych potwierdzają słuszność dokonanych przez Durydiwkę (2020) wydzieleń odnoszących się do kategorii turystów odwiedzających klasztory w ogóle, choć ze względu na specyfikę i możliwości klasztorów klauzurowych z wyraźną dominacją turystów motywowanych religijnie. Nawet grupa, którą

${ }^{2}$ Telefoniczne badanie sondażowe przeprowadzone w dziewięciu klasztorach (w tym dwóch klauzurowych) dotyczące ich oferty skierowanej dla świeckich (Durydiwka 2020, s. 9-10). 
autorka nazywa „uczestnikami warsztatów terapeutycznych”, jest tutaj poniekąd reprezentowana, choć owe „terapie” świadczone przez klasztory klauzurowe nie są sformalizowane i mają wysoce indywidualny charakter.

Z uwagi na specyfikę polskich klasztorów klauzurowych oraz sądząc po deklaracjach tych, które wzięły udział w badaniu, wskazujących na niewielką pod względem liczebności świeckich gości skalę zjawiska, nie wydaje się, iż udział tych obiektów w turystyce monastycznej będzie się zwiększał. Pod tym względem różnią się one od klasztorów apostolskich, których oferta (przynajmniej niektórych) ewoluuje w kierunku coraz bardziej turystycznej w klasycznym słowa tego znaczeniu: traktującej wygodę i komfort pobytu gości na równi z funkcją religijną, duchową czy terapeutyczną (Durydiwka 2020). Niewielkie grono przyjmowanych do klasztorów klauzurowych świeckich nadaje jednak ich doświadczeniu charakteru wyjątkowości, ze strony gospodarzy zaś świadczy o rzeczywistym skupieniu na tym, co skłoniło gości „zza drugiej strony kraty” do odwiedzin klasztoru.

Przedłożone w tekście badania mają charakter eksploracyjny, wskazują jednakże na intrygujące, lecz jednocześnie trudne pole badawcze. $Z$ uwagi na wrażliwy charakter motywacji, którymi kierują się turyści odwiedzający klasztory klauzurowe, i ograniczone możliwości w dotarciu do nich, przedstawiono zjawisko w sposób możliwie pełny, ale jednostronny, tak jak jest ono postrzegane przez goszczące świeckich klasztory. Obraz ten nie powstałby jednak bez życzliwej pomocy klasztorów, które wzięły udział w badaniu.

\section{Literatura:}

Abbruzzese S., 2014, Chapter 1. Monastic Asceticism and Everyday Life, [w:] E. Pace, Annual Review of the Sociology of Religion. Volume 5: Sociology and Monasticism, Between Innovation and Tradition, BRILL, 3-20.

Annuarium Statisticum Ecclesiae in Polonia, 2019, http://iskk.pl/images/stories/Instytut/dokumenty/Annuarium_Statisticum_2019.pdf (dostęp: 23.05.2020).

Aulet S., Mundet L., Vidal D., 2017, Monasteries and tourism: interpreting sacred landscape through gastronomy, Rev. Bras. Pesq. Tur. São Paulo, 11(1),175-196.

Catholic Church Statistics, 2019, Agenzia Fides, http://www.fides.org/en/news/66809-VATICAN_Catholic_Church_Statistics_2019(dostęp: 23.05.2020).

Choe J., McNally J., 2013, Buddhism in the United States: An ethnographic study, International Journal of Religious Tourism and Pilgrimage, I(1), 92-100.

Cox Hall A., 2018, Living on a prayer: neo-monasticism and socio-ecological change, Religion, 48:4, 678-699, DOI: 10.1080/0048721X.2018.1520752.

Durydiwka M., 2020, „Urlop w klas:tor «e”, czyli oferta religijno-rekreacyjna obiektów klas:tornych w Polsce i profil gości, Turystyka Kulturowa, Nr 2/2020, 7-23. 
Eliade M., 1994, Historia wierzeń i idei religijnych. Tom II. Od Gautamy Buddy do poczq̨tków chrześcijanstwa, Instytut Wydawniczy PAX, Warszawa.

Gilli M., Ferrari S., 2017, Marginal places and tourism: the role of Buddhist centers in Italy, Journal of Tourism and Cultural Change, 15:5, 422-438, DOI: 10.1080/14766825.2016.1170840.

Gilli M., Palmisano S., 2016, Holy holidays: why is monastic tourism attractive? Insight from Italian Catholic monasticism, [w:] I. Jonveaux, S. Palmisano (red.), Monasticism in Modern Times, Routledge. London-New York, 99-115.

Jackowski A., 2003, Święta przestræen świata. Podstawy geografii religii, Wydawnictwo UJ, Kraków. Jewdokimow M., 2017, Od inspiracji monastycznych do socjologicznych badań nad klasztorami $i$ sakonami, Studia Socjologiczne, 4 (227), 209-227.

Jonveaux I., 2011, Ascetism: an endangered value? Mutations of ascetism in contemporary monasticism, Scripta Instituti Donneriani Aboensis, 23, 186-196. https://doi.org/10.30674/scripta.67386.

Jonveaux I., 2014, Redefinition of the Role of Monks in Modern Society: Economy as Monastic Opportunity, Annual Review of the Sociology of Religion, 71-86, DOI: https://doi. org/10.1163/9789004283503_006.

Kleymann B., Malloch H., 2010, The rule of Saint Benedict and corporate management: employing the whole person, Journal of Global Responsibility, Vol. 1, No. 2, 207-224.

Palmisano S., Jewdokimow M., 2019, New monasticism: An answer to the contemporary challenges of catholic monasticism? Religions, 10, 411; doi:10.3390/rel10070411.

Podgórski Z., Charzyński P., Skiera K., 2016, Charakterystyka turystów odwiedzajqcych sanktuarium maryjne w Górce Klasжtornej w gminie Łobżenica, [w:] J. Mokras-Grabowska, J. Latosińska (red.), Kultura i turystyka - sacrum i profanum, Regionalna Organizacja Turystyczna Województwa Łódzkiego, Łódź, 165-179.

Ryan M.M., Haslam-McKenzie F.H., 2003, A monastic tourist experience: the packaging of a place, Tourism Geographies, 5:1, 54-70. DOI: 10.1080/1461668032000034060.

van Tongeren L., 2016, Visiting abbeys. Changing monastic identities and the attraction of abbeys, [w:] I. Jonveaux, S. Palmisano (red.), Monasticism in Modern Times, Routledge. LondonNew York, 81-98.

Weber M., 2014, Etyka protestancka a duch kapitalizmu. Protestanckie „sekty” a duch kapitalizmu, Aletheia, Warszawa.

Wrzesień W., 2017, Oblicza anomii, Ruch Prawniczy, Ekonomiczny i Socjologiczny, Rok LXXIX, zeszyt 4, 285-304.

Zimnica-Kuzioła E., 2015, Emigracja do swiata klauzurowego - na podstawie relacji sióstr zakonnych, Acta Universitatis Lodziensis. Folia Sociologica, 53, 71-91.

https://klauzura.katolik.pl/xhtml/klasztory/adresy/ (dostęp: 25.04.2020).

https://klauzura.katolik.pl/xhtml/statystyka/2019/ (dostęp: 26.04.2020).

https://zakony-zenskie.pl/statystyka/ (dostęp: 24.04.2020). 


\title{
Załącznik 1.
}

Formularz ankiety skierowanej do klasztorów podejmujących działalność w zakresie oferowanych świeckim możliwości czasowego odosobnienia w klasztorze, kontemplacji lub życia w zgodzie z rutyną dnia codziennego zakonu, opracowanie własne

\section{Szanowni Państwo,}

w wwiqะku ะ prowadzonymi badaniami nad tww. turystykq ucieckkowq w Polsce, wwracam się z prośbq o udzielenie informacji na temat dziatalności klasztorów kontemplacyjnych w Polsce na ræecะ swieckich w sakresie oferowanych im możliwości czasowego odosobnienia, kontemplacji lub sycia w sgodzie z rutyna dnia codziennego sakonu. Ankieta skierowana jest do klasztorów, które prowad:q takq dziatalność.

Wyniki badań (zbiorcse) zostanq wykorsystane w pracy naukowej celem publikacji w periodykach naukowych.

Ankieta liczy 11 pytań.

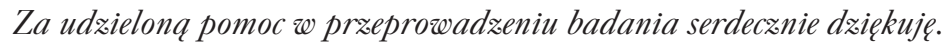

\author{
dr Dagmara Chylińska \\ Uniwersytet Wrocławski \\ dagmara.chylińska@uwr.edu.pl
}

1. Działalność na rzecz świeckich ma charakter (możliwy jest wybór wielu odpowiedzi w zależności od zakresu prowadzonej działalności):

a. udostępnienia świeckim pobytu/odosobnienia na określony czas, bez wymogu podejmowania jakichkolwiek praktyk religijnych

b. udostępnienia świeckim pobytu/odosobnienia na określony czas, świeccy organizują sobie czas i sposób modlitwy samodzielnie

c. udostępnienia świeckim pobytu/odosobnienia w klasztorze i umożliwienia uczestnictwa we wspólnych modlitwach zgromadzenia zakonnego lub innych praktykach religijnych

d. udostępnienia świeckim pobytu/odosobnienia w klasztorze i stworzenia możliwości uczestnictwa w codziennym życiu klasztoru poza czynnościami religijnymi zarezerwowanymi tylko dla członków zgromadzenia

e. inny, jaki? (proszę wpisać)

2. Od kiedy prowadzona jest ta działalność - proszę wpisać rok

3. Czy o przyjęciu do klasztoru świeckich w celu zapewnienia im czasowego pobytu/ odosobnienia decydują jakieś specjalne kryteria?
a. tak, decydujące są motywacje religijne świeckiego
b. tak, brane są pod uwagę różne, także pozareligijne kryteria (np. płeć, wiek, rodzaj potrzeb)
c. nie, przyjmujemy wszystkich, którzy wyrażają takie pragnienie 
4. Czy wymieniona przez Państwa działalność na rzecz świeckich ma charakter:
a. incydentalny
b. regularny, w określonych porach roku wynikających z kalendarza liturgicznego
c. regularny, ale bez wyraźnych związków z kalendarzem liturgicznym

5. Jeśli goście mają możliwość uczestniczyć w codziennych zajęciach prowadzonych w klasztorze, są nimi (możliwe jest wskazanie wielu odpowiedzi):
a. praca w kuchni
b. praca w ogrodzie
c. inne prace porządkowe
d. czytanie lektur
e. rozmowy indywidualne z członkami zakonu
f. rozmowy grupowe z członkami zakonu
g. uczestnictwo w różnego rodzaju terapiach duchowych
h. uczestnictwo w terapiach behawioralnych
i. uczestnictwo w zbiorowej modlitwie
j. uczestnictwo we mszy
k. kontemplacja
1. wspólny śpiew
m. spowiedź
n. pokuta
o. pomoc w działalności zewnętrznej (np. opiekuńczej) poza klasztorem
p. inne, jakie? (proszę wymienić)

6. Na podstawie Państwa własnych obserwacji - goście, korzystający z oferty klasztoru w opisywanym zakresie to odwiedzający:
a. jednokrotni
b. powracający od czasu do czasu
c. powracający wielokrotnie
d. powracający wielokrotnie i finalnie z zamiarem dołączenia do wspólnoty religijnej
e. wszystkie wymienione grupy „po trochu”

7. Świeccy, korzystający z gościny Zakonu, to na podstawie Państwa obserwacji (możliwy wielokrotny wybór):
a. osoby poszukujące sensu życia, szeroko rozumianej duchowości
b. osoby poszukujące odnowy religijnej lub religijnego rozwoju
c. osoby zagubione
d. osoby wątpiące
e. osoby uciekające od czegoś/przed czymś
f. osoby szukające odmiany
g. osoby ciekawe zakonnego życia
h. osoby szukające ukojenia w prostym, uregulowanym regułą zakonnym życiu
i. osoby przygotowujące się do życia zakonnego
j. inne, jakie? (proszę wymienić) 
8. Rocznie odwiedza Państwa klasztor w celach wymienionych w ankiecie (pobyt/ odosobnienie):
a. pojedyncze osoby
b. od kilkunastu do kilkudziesięciu osób
c. od kilkudziesięciu do kilkuset osób
d. więcej niż kilkaset osób rocznie

9. Proszę określić na podstawie własnych obserwacji, jak długo trwa przeciętny pobyt osoby świeckiej szukającej w klasztorze pobytu/odosobnienia:
a. do 7 dni
b. powyżej jednego tygodnia do jednego miesiąca
c. powyżej jednego miesiąca

10. Są Państwo klasztorem:
a. żeńskim
b. męskim

11. Proszę wpisać regułę zakonu:

\section{Dziękuję!}

\section{Załącznik 2.}

Formularz ankiety skierowanej do klasztorów niepodejmujących działalności w zakresie oferowania świeckim możliwości czasowego odosobnienia w klasztorze, kontemplacji lub życia w zgodzie z rutyną dnia codziennego zakonu, opracowanie własne

Szanowni Państwo,

w zwiqzku \& prowadzonymi badaniami nad tww. turystykq ucieckkowq, swracam się \& prośbq o udzielenie informacji na temat działalności klasztorów kontemplacyjnych w Polsce na ræecz swieckich w zakresie oferowanych im możliwości czasowego odosobnienia, kontemplacji lub sycia w agodzie z rutyna dnia codziennego zakonu. Ankieta skierowana jest do klas:torów, które nie prowad:q takiej dziatalności.

Wyniki badań (zbiorcze) zostanq wykorzystane w pracy naukowej celem publikacji w periodykach naukowych. Ankieta liczy 5 pytań.

Za udzielona pomoc w præeprowadzeniu badania serdec*nie dziękuje.

dr Dagmara Chylińska

Uniwersytet Wrocławski

dagmara.chylińska@uwr.edu.pl

1. Jeśli nie prowadzą Państwo działalności na rzecz świeckich polegającej na zapewnieniu im pobytu/odosobnienia dla różnych, także poza religijnych celów, proszę o określenie powodów, które stoją za taką decyzją (dowolna liczba odpowiedzi):

a. nie pozwala na to reguła zakonna

b. nie jesteśmy w stanie zapewnić świeckim warunków pobytu (lokalowych, żywieniowych itp.) 
c. działalność taka wpływałaby negatywnie na organizację życia zakonnego

d. nie widzimy zainteresowania ze strony świeckich taką ofertą

e. nie widzimy konieczności podejmowania takiej działalności

f. inne, jakie? (proszę wpisać)

2. Czy przewidują Państwo zmianę decyzji co do przyjmowania osób świeckich do Zakonu w celu zapewnienia im czasowego pobytu lub odosobnienia?
a. tak
b. nie
c. trudno powiedzieć

3. Proszę wskazać, co mogłoby wpłynąć na zmianę decyzji w sprawie przyjmowania osób świeckich na potrzeby ich krótkotrwałego pobytu/odosobnienia w Zakonie podejmowanego $\mathrm{w}$ różnych celach:

a. nie przewidujemy zmiany naszej decyzji/trudno powiedzieć

b. napływ indywidualnych lub zbiorowych próśb ze strony świeckich, rozpatrywanych przez Zakon indywidualnie

c. zmiana naszych warunków organizacyjnych, lokalowych lub żywieniowych, które umożliwiłyby przyjmowanie świeckich gości na czas zorganizowanego im pobytu/odosobnienia d. inne, jakie?

4. Są Państwo klasztorem:
a. żeńskim
b. męskim

5. Proszę wpisać regułę Zakonu

Dziękuję!

Dagmara Chylinska

Uniwersytet Wroctawski

Instytut Geografii i Rowwoju Regionalnego

Pl. Uniwersytecki 1, 50-137 Wroctaw

dagmara.chylinska@uwr.edu.pl 